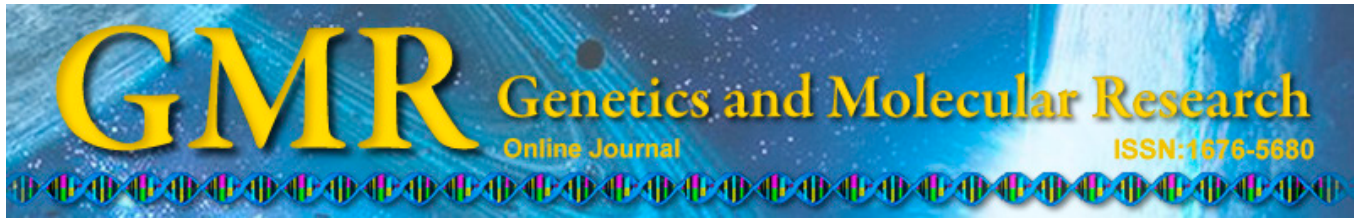

\title{
Ion beam transformation with corn DNA alters proteinase expression in rice seedling roots
}

\author{
W.C. Li ${ }^{1}$, S.D. Ji' ${ }^{1}$, X.C. Wang', Z.K. Li ${ }^{1}$, H.C. Zhang ${ }^{1}$, C.Z. Tian', \\ Y.L. Liu ${ }^{1}$ and C.X. Duan ${ }^{2}$ \\ ${ }^{1}$ College of Life Sciences, Henan Normal University, Xinxiang, China \\ ${ }^{2}$ National Key Facility for Crop Gene Resources and Genetic Improvement, \\ Institute of Crop Science, Chinese Academy of Agricultural Sciences, \\ Beijing, China
}

Corresponding authors: S.D. Ji / C.X. Duan

E-mail: jishengdong_sd@163.com / duancanxing_cx@163.com

Genet. Mol. Res. 14 (2): 7258-7266 (2015)

Received January 9, 2015

Accepted May 14, 2015

Published June 29, 2015

DOI http://dx.doi.org/10.4238/2015.June.29.19

ABSTRACT. Corn DNA was introduced into dry seeds of rice (cv. 'YuJing-6') by ion beam irradiation. Proteinase activities in rice seedling roots were subsequently analyzed by renaturation electrophoresis at $\mathrm{pH}$ 4.5, 7.0, and 8.5. Proteinase activity was more pronounced on gels at higher $\mathrm{pH}$. Irradiation of rice seedling roots caused the loss of some proteinase bands at all $\mathrm{pH}$ conditions although a novel $50-\mathrm{kDa}$ band was found at both $\mathrm{pH} 7.0$ and 8.5. No new proteinase activity was detected at $\mathrm{pH} 4.5$. However, novel bands and bands showing stronger activity were observed at $\mathrm{pH} 7.0$ and 8.5. The data indicate that the expression of proteinases in rice seedling roots was altered following low energy ion beam mediated transformation with corn DNA.

Key words: Ion beam; Transformation; Rice; Proteinase 


\section{INTRODUCTION}

The technique of transducing exogenous DNA using ion beam irradiation was first developed and applied to the genetic transformation of crop plants by Chinese scientists ( $\mathrm{Yu}$, 1998). It has provided a new means for achieving wide hybridization in crop breeding and is therefore attractive to plant breeders (Xuan et al., 2004; Jiao et al., 2006; Lu et al., 2008; Ji et al., 2009). However, the process of DNA transformation is complicated; it may play a dual role in mutagenicity and transfer of foreign DNA. Thus, at present, the mechanism by which ion beam mediated transformation is achieved remains unclear.

Enzyme is a connection between gene and its traits. Isoenzyme analysis is an effective method for identifying genetic mutations and gene transfer at the molecular level. The information from such analyses can give insights into gene expression. For example, the loss of bands on gels could indicate alteration of enzyme activity or could identify potential changes in gene expression triggered by introduced exogenous DNA (Zhu et al., 2000; Ji et al., 2003). Proteinases are important enzymes and potentially of value for investigating spontaneous or induced genetic changes. These enzymes are involved in gene expression, cell differentiation, protein degradation, specific modification, biological stress, growth, development, and reproduction (Vasslli and Pepper, 1994). They are therefore valuable marker enzymes of genetic variation. Renaturation electrophoresis (SDS-PAGE) was developed in the early 1980s to study the structure, properties, and functions of enzymes (Heussen and Dowdle, 1980; Neuhaus-Steinmetz et al., 1994). In recent years, this method has been applied to proteases of wheat and rice (Ji et al., 2001, 2003, 2008; Wang et al., 2008).

Here, we introduced corn DNA into dry seeds of rice (cv. YuJing-6) by ion beam irradiation. We then screened the roots of the rice plants for proteinase activity, using renaturation electrophoresis at different $\mathrm{pH}$ values to investigate the effects at the proteinase level of DNA transfer. This analysis also enabled detection of the effects of corn DNA on the expression of root proteinases and allowed identification of alterations to enzyme structures. These data will provide a basis for positional cloning, for the functional analysis of exogenous genes, and possible insights into the mechanism of genetic transformation mediated by ion beam irradiation.

\section{MATERIAL AND METHODS}

\section{Materials}

Pure grade acrylamide (USB Corporation, USA), bisacrylamide (Fluka, USA), gelatin (Sigma-Aldrich, USA), TEMED (Bio-Rad, USA), SDS (Gibco, USA), Tris-base (Gibco), and Triton X-100 (FARCO Chemical Supplies, Hong Kong) were used in the experiments.

Oryza sativa L. (cv. YuJing-6) seeds were provided by the Xinxiang Academy of Agricultural Sciences; Zea mays L. was obtained from the Henan Academy of Agricultural Sciences.

\section{Extraction of maize genome DNA}

We used the cetyltrimethylammonium bromide method to extract corn total genomic DNA using the previously described method (Murray and Thompson, 1980; Doyle and Doyle, 1990). The extracted corn DNA was diluted to $100 \mu \mathrm{g} / \mathrm{mL}$ in $0.1 X$ SSC buffer, and stored at $4^{\circ} \mathrm{C}$. 


\section{Treatment of rice seeds}

Peeled rice seeds (germ upward) were irradiated with a $\mathrm{N}^{+}$ion beam using a TITAN ion machine $\left(25 \mathrm{KeV}, 3.0 \times 10^{17} \mathrm{~N}^{+} / \mathrm{cm}^{2}\right)$. The treatment was performed at the Key Laboratory of beam bio-engineering, Zhengzhou University. The seeds were then soaked in the $100 \mu \mathrm{g} /$ $\mathrm{mL}$ DNA solution. Three control groups $(\mathrm{n}=50)$ were also initiated. The following seed treatment groups were established: group $\mathrm{A}, \mathrm{N}^{+}$irradiation + corn DNA; group $\mathrm{B}, \mathrm{N}^{+}$irradiation + $0.1 \mathrm{X}$ SSC; group C, corn DNA only; group D, 0.1X SSC only. Three replicates of each treatment group were set up. The seeds were incubated at $30^{\circ} \mathrm{C}$ for $18 \mathrm{~h}$.

\section{Cultivation and extraction of seedlings}

Seeds were incubated at $37^{\circ} \mathrm{C}$ incubator until they germinated. When seedlings had one leaf, the roots were excised. Twenty seedlings per group were chosen at random for root sampling. The root samples were placed in liquid nitrogen and ground to a powder; the powder was then resuspended in $7 \mathrm{~mL} 0.15 \mathrm{M} \mathrm{NaCl}$. The suspension was centrifuged at 12,000 rpm for $15 \mathrm{~min}$ and the supernatant was stored at $-20^{\circ} \mathrm{C}$.

\section{SDS-PAGE analysis of proteinases}

We added proteinase degradable gelatin to the polyacrylamide gel mix in order to avoid displacement during electrophoresis. The combination of SDS and proteinases ensured that the enzymes were reversibly denatured. After electrophoresis, the gel was washed with Triton X-100 to remove the SDS. The proteinases therefore recover their activity and digest the gel where they are located. After digestion, the gel was stained with Coomassie brilliant blue R250; digested regions do not stain and appear as colorless bands (termed here "negative bands" or "proteinase bands") on a blue background. The locations of the bands reflect the molecular sizes of the proteinases, and their intensity reflects enzymatic activity. The relative activity of the proteinase was also calculated by densitometry and gel imaging analysis. In the present study, we varied the $\mathrm{pH}$ of the solution used to investigate enzyme activity to cover acidic, neutral, and alkaline conditions (Neuhaus-Steinmetz et al., 1994; Xu et al., 1998). Sample buffer (10 mL 87\% glycerol, $3.5 \mathrm{~mL} \mathrm{0.5} \mathrm{M} \mathrm{Tris-HCl,} 10 \mathrm{~g}$ SDS, double distilled water to a final volume of $100 \mathrm{~mL}$ ) was added to samples before electrophoresis. The samples (50 $\mu \mathrm{g})$ and protein standards $(200,130,97,66$, and $43 \mathrm{kDa})$ were added to each sample well and SDS-G-PAGE was performed to separate proteinases (Neuhaus-Steinmetz et al., 1994). The concentrations of the separating and stacking gels were 10 and 5\%, respectively. The initial electric current of $\leq 50 \mathrm{~V}$ was applied, with a subsequent constant current of $\leq 10 \mathrm{~mA}$ (at $4^{\circ} \mathrm{C}$ ). When the dye passed from the stacking gel, voltage was increased to $\leq 100 \mathrm{~V}$ (at $4^{\circ} \mathrm{C}$ ). Electrophoresis was continued until the dye (1\% bromophenol blue) ran off the gel bottom.

The gel was washed with $250 \mathrm{~mL}$ wash buffer $(12 \mathrm{~mL}$ Triton X-100, $3.03 \mathrm{~g}$ Tris to a final volume of $500 \mathrm{~mL}$ with double distilled water, $\mathrm{pH}$ 7.0) for $30 \mathrm{~min}, 2$ x $5 \mathrm{~min}$ with distilled water, and 1 x 5 min with double distilled water. The gel was placed into medium ( $3.7 \mathrm{~g}$ glycerin, $0.37 \mathrm{~g} \mathrm{CaCl}_{2}$ in $500 \mathrm{~mL}$ double distilled water, $\mathrm{pH} \mathrm{7.0)}$ for $5 \mathrm{~min}$. After washing, the gel was incubated at $37^{\circ} \mathrm{C}$ for $24 \mathrm{~h}$ at $\mathrm{pH} 4.5, \mathrm{pH} 7.0$, or $\mathrm{pH} 8.5$. The gel was then fixed, stained, bleached, and scanned (Laemmli, 1970) and stored either dry or in destaining solution. 


\section{Assay of proteinase activity and molecular weight}

Proteinase activities and molecular weights were determined using a gel imaging analysis system (Tanon, China).

\section{RESULTS}

\section{Proteinase activity at $\mathrm{pH} 4.5$}

Unirradiated control seeds incubated with 0.1X SSC (group D) produced four bands of $38,66,188$, and $234 \mathrm{kDa}$ (Figure 1). Compared with group D, the 188-kDa band was not found in group A (irradiated + corn DNA), the 188- and 234-kDa bands were not found in group B (irradiated + 0.1X SSC), and the 234-kDa band was not found in group C (unirradiated + corn DNA). No novel proteinases were found in these groups. The treatments in groups $\mathrm{A}, \mathrm{B}$, and $\mathrm{C}$ appeared to inhibit proteinase expression.

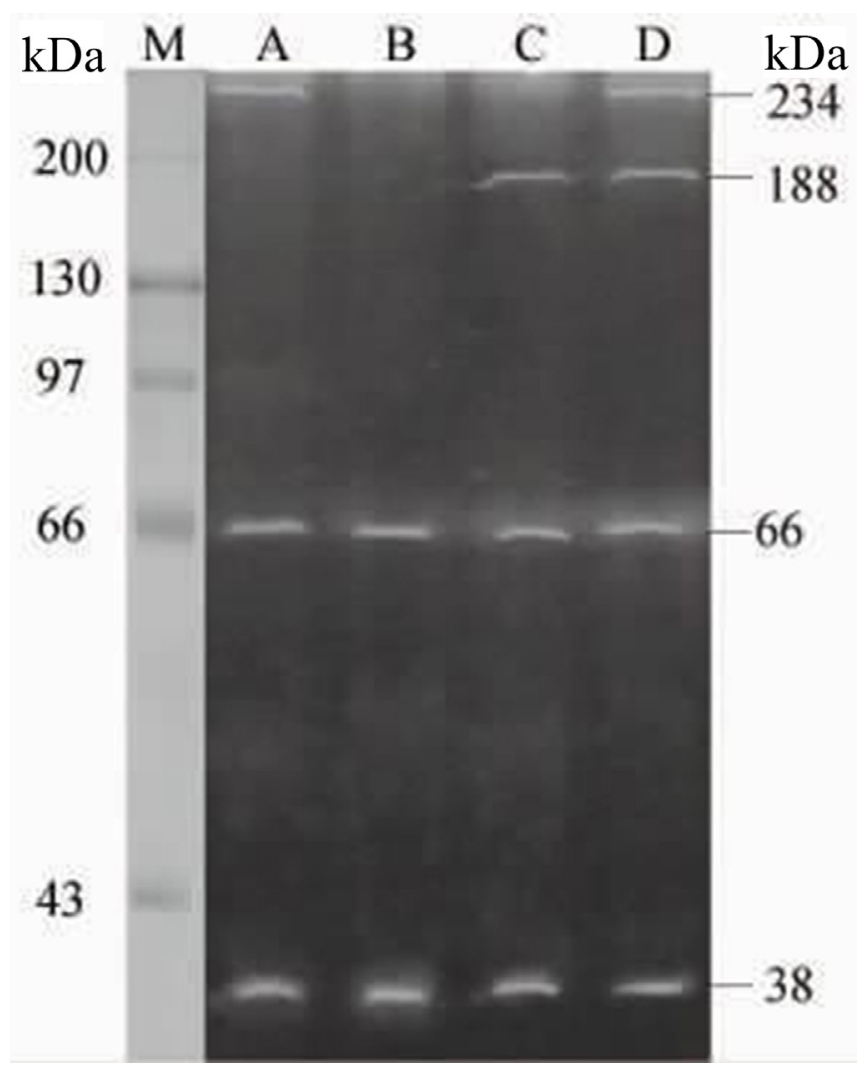

Figure 1. Proteinases from roots of rice seedlings separated by SDS-PAGE under acidic ( $\mathrm{pH} 4.5$ ) conditions. Four treatment groups are shown: (A) seeds treated with $\mathrm{N}^{+}$ion beam irradiation and incubated in corn DNA/0.1X SSC; (B) seeds treated with $\mathrm{N}^{+}$ion beam irradiation and incubated in $0.1 \mathrm{X} \mathrm{SSC}$; (C) unirradiated seeds incubated in corn DNA/0.1X SSC; (D) unirradiated seeds incubated in 0.1X SSC. M = standard molecular weight proteins. 


\section{Proteinase activity at $\mathrm{pH} 7.0$}

In the unirradiated controls (group D), six bands of 52, 54, 165, 200, 212, and $234 \mathrm{kDa}$ were present (Figure 2). In comparison, group A had four novel bands of 50, 62, 77, and $98 \mathrm{kDa}$; the bands at 54 and $165 \mathrm{kDa}$ were absent. Compared to groups $\mathrm{B}$ and $\mathrm{C}$, four novel bands were present at $62,77,98$, and $234 \mathrm{kDa}$ in group A. These results indicate some new proteinases were expressed in rice seedlings transformed with corn DNA. At the same time, ion beam irradiation might have inhibited expression of some neutral proteinases in rice seedlings. In comparison to group $\mathrm{D}$, the group B seedlings had a new band at $50 \mathrm{kDa}$, and three bands at 52, 165, and 234 $\mathrm{kDa}$ were absent. This suggests that irradiation inhibited expression of some neutral proteinases but also induced novel neutral proteinases. Compared to group D, three bands at 54, 165, and $234 \mathrm{kDa}$ were absent in group C. This suggests that corn DNA could inhibit neutral proteinases.

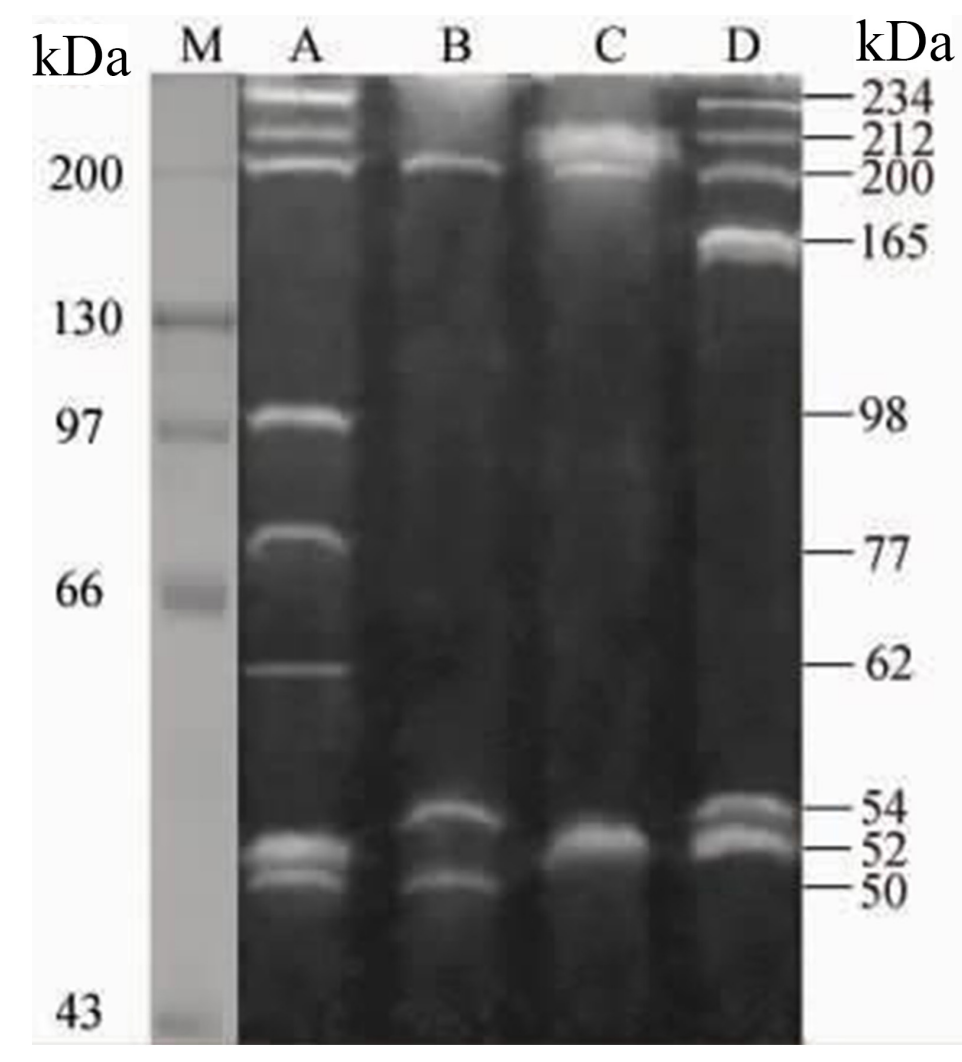

Figure 2. Proteinases from roots of rice seedlings separated by SDS-PAGE under neutral (pH 7.0) conditions. Four treatment groups are shown: (A) seeds treated with $\mathrm{N}^{+}$ion beam irradiation and incubated in corn DNA/0.1X SSC; (B) seeds treated with $\mathrm{N}^{+}$ion beam irradiation and incubated in $0.1 \mathrm{X} \mathrm{SSC}$; (C) unirradiated seeds incubated in corn DNA/0.1X SSC; (D) unirradiated seeds incubated in 0.1X SSC. Lane $M=$ standard molecular weight proteins.

\section{Proteinase activity at $\mathrm{pH} 8.5$}

Group D seedlings had seven bands located at 52, 54, 74, 165, 200, 212, and $234 \mathrm{kDa}$ 
(Figure 3). In comparison, group A had five novel bands at 50, 60, 62, 63, and $98 \mathrm{kDa}$, and two bands at 54 and $165 \mathrm{kDa}$ were absent. Compared to groups $\mathrm{B}$ and $\mathrm{C}$, five novel bands at 60 , $62,63,98$, and $234 \mathrm{kDa}$ were present in group $\mathrm{A}$. These results indicate that ion beam mediated DNA transformation induced expression of some proteinases under alkaline conditions. Compared to group D, group B seedlings had a new band at $50 \mathrm{kDa}$ and had lost three bands at 52, 165, and $234 \mathrm{kDa}$. Group C seedlings had lost three bands at 54, 165, and $234 \mathrm{kDa}$ compared to group D, while the intensity of the $212-\mathrm{kDa}$ band was noticeably increased. Thus, the corn DNA seemed to suppress expression of some alkaline proteinases, promote expression of other alkaline proteinases, and induce overexpression of some proteinase genes.

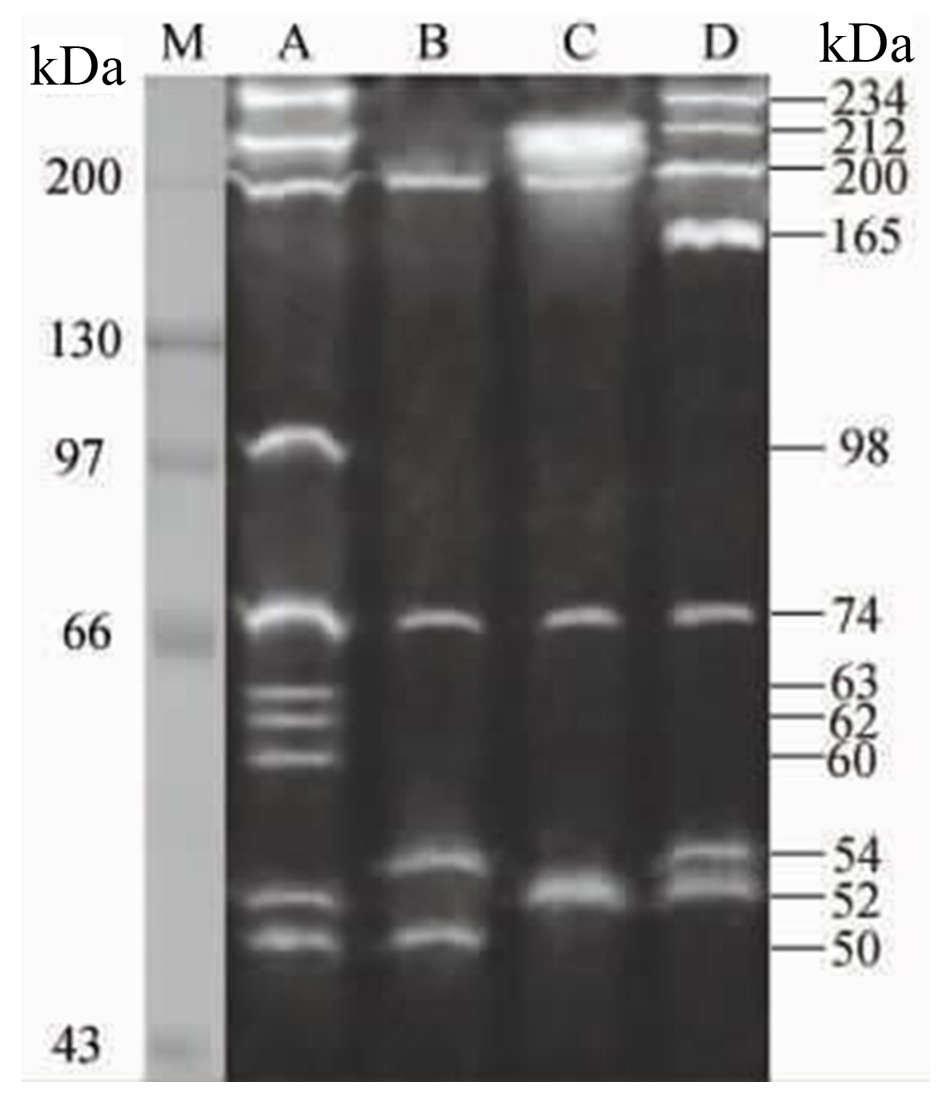

Figure 3. Proteinases from roots of rice seedlings separated by SDS-PAGE under alkaline ( $\mathrm{pH} 8.5)$ conditions. Four treatment groups are shown: (A) seeds treated with $\mathrm{N}^{+}$ion beam irradiation and incubated in corn DNA/ $0.1 \mathrm{X}$ SSC; (B) seeds treated with $\mathrm{N}^{+}$ion beam irradiation and incubated in $0.1 \mathrm{X} \mathrm{SSC} ;(\mathbf{C})$ unirradiated seeds incubated in corn DNA/0.1X SSC; (D) unirradiated seeds incubated in 0.1X SSC. Lane $M=$ standard molecular weight proteins.

\section{Effect of pH on proteinase expression}

The analyses showed that the activities of proteinases in rice seedlings varied significantly at different $\mathrm{pH}$ (Figures 1, 2, and 3). There was evidence of a greater range of proteinase activities with increasing $\mathrm{pH}$. Under acidic conditions, proteinase activity was generally 
quite weak. However, under neutral or alkaline conditions, proteinase activities were strong. In comparison to the other groups, seedlings of group B showed a loss of some bands at all three $\mathrm{pH}$, although they did show a novel band $(50 \mathrm{kDa})$ at $\mathrm{pH} 7.0$ and 8.5. Possibly, this effect might be due to ion beam induced mutation. No new bands were detected at $\mathrm{pH} 4.5$ in seedlings from the DNA transformed group, although novel bands were seen at $\mathrm{pH} 7.0$ and 8.5. These results indicated that ion beam irradiation might induce the expression of neutral and alkaline proteinases.

\section{DISCUSSION}

The use of ion beam irradiation to mediate DNA transformation has notable effects on target cells. The ion beam can alter the structure of cell wall and cell membrane, and cause the formation of micro-channels formed at the surface of cell, through which exogenous DNA can easily enter. The positive ion beam induces charge exchange and electriferous ion deposition and results in the accumulation of a positive charge at the micro-channel. The negatively charged exogenous DNA can then actively enter the cell. Ion-beam irradiation may damage nuclear DNA strands in the cell and trigger DNA repair processes that may make it easier for exogenous DNA to be integrated into the cell (Yu et al., 1993). Song et al. (1998) reported that ion beam irradiation causes extensive damage to DNA and induces biological mutations. The mechanism of ion beam-mediated transfer of exogenous DNA is complex and may result in mutations. Analysis of protein expression in transgenic organisms (Ji et al., 2001; Xuan et al., 2004; Huang et al., 2008) or isozyme analysis (Ji et al., 2003, 2008) provides some insight into the mechanism of ion beam-mediated transfer of foreign DNA at the protein level.

In this study, we introduced corn DNA into rice seeds using $\mathrm{N}^{+}$ion beam irradiation and analyzed proteinase expression using SDS-PAGE. Compared to the three control groups (groups B, C, and D), we found three new bands at 62, 77, and $98 \mathrm{kDa}$ and noted the absence of a band at $54 \mathrm{kDa}$ in transformed rice seedlings in gels run under neutral conditions (Figure 2). Under alkaline conditions, the gels from the seedlings had new bands at 60, 77, and 98 $\mathrm{kDa}$, and lacked a band at $54 \mathrm{kDa}$ compared to control groups (Figure 3). Exogenous DNA inserted into a recipient cell may be expressed immediately or get integrated into the recipient's genome. It is possible that these effects are responsible for the expression of new bands in the transformed seedlings. Another explanation for the newly appeared bands is that they resulted from changes in gene expression after transformation. Moreover, ion beam induced mutation or the exogenous DNA might be responsible for newly appeared bands. These possible explanations are consistent with the results of ion beam transformation of soybean DNA into wheat (Ji et al., 2001). These observations suggest that the transformation method using ion beam irradiation may induce novel gene expression at the protein level. However, whether the new proteins are the product of exogenous genes is still unknown and needs further study. The missing band at $54 \mathrm{kDa}$ might be a consequence of the interaction of ion beam irradiation, mediated solution, and exogenous DNA. Our results indicate that expression of proteinases both decreased and increased in rice seedlings transformed with corn DNA using ion beam irradiation. They also reveal differences in proteinase expression in transformed rice seedlings.

At $\mathrm{pH} 4.5$, the $234-\mathrm{kDa}$ band was missing in group $\mathrm{C}$ and the 188 - and $234-\mathrm{kDa}$ bands were missing in group B. No new bands were detected in groups B or C. The results indicate that corn DNA and $\mathrm{N}^{+}$ion beams inhibited proteinase expression under acidic conditions, but 
that the effect of the $\mathrm{N}^{+}$ion beam radiation was stronger. At $\mathrm{pH} 7.0$ and 8.5, the 54-, 165-, and $234-\mathrm{kDa}$ bands were missing in group $\mathrm{C}$, although activity of the $212-\mathrm{kDa}$ band was upregulated in this group. In group B, the 52-, 165-, 212-, and 234-kDa bands were missing and a new band was detected at $50 \mathrm{kDa}$. Thus, the inhibition of proteinase activity in group $\mathrm{B}$ was similar to that in group $\mathrm{C}$ under neutral and alkaline conditions. Moreover, the outcomes were similar to those under acidic conditions. The new band $(50 \mathrm{kDa})$ detected after ion beam irradiation may be associated with the treatment or with genetic mutation. Further research will be needed to determine the mutagenic effects of ion beam irradiation. The effect of dipping seeds into a solution containing corn DNA on proteinase activities remains unclear. It is possible that there is a change in gene expression regulation induced by the exogenous DNA. At the seedling stage, no new bands were found in group C. Thus, it is not feasible to simply soak seeds to introduce exogenous DNA into plants.

At present, it is unclear whether using a lower radiation dose to avoid mutation is better than using a larger radiation dose to increase the level of mutation. Further studies need to be carried out to optimize the radiation dose for transforming plant seeds.

\section{Conflicts of interest}

The authors declare no conflict of interest.

\section{ACKNOWLEDGMENTS}

Research supported by the National Natural Science Foundation of China (\#1304317), Research cooperation projects (\#112106000037), and Henan Province Science and Technology Research (\#132102310303).

\section{REFERENCES}

Doyle JJ and Doyle JL (1990). Isolation of plant DNA from fresh tissue. Focus 12: 13-15.

Heussen C and Dowdle EB (1980). Electrophoretic analysis of plasminogen activators in polyacrylamide gels containing sodium dodecyl sulfate and copolymerized substrates. Anal. Biochem. 102: 196-202.

Huang GP, Yang JF, Guo CJ, Huang JP et al. (2008). Analysis on proteomic profiling of human bone marrow mesenchymal stem cells transduced with hTERT gene. Chin. J. Biochem. Mol. Biol. 24: 315-328.

Jiao Z, Gu YH, Li JY, Song B et al. (2006). RAPD marker analysis of high-protein offspring plants of wheat transformed with soybean DNA through particle beam mediation. Acta Bot. Boreali-Occidentalis Sin. 26:1878-1882.

Ji SD, Li JX, Zhao JJ, Xu CS et al. (2001). The analysis of proteinase zymography of transgenic wheat leaves by irradiation of low energy. J. Triticeae Crops 21: 5-8.

Ji SD, Qin GY, Geng S, Xia M et al. (2003). Analysis of properties and types of proteinases in wheat male sterility variants with soybean DNA mediated by low energy ion beam. Acta Agron. Sin. 29: 797-800.

Ji SD, Zhang XW, Lu SX, Zhu HY et al. (2008). Varieties and activity of proteinases in low-protein variants lines of wheat transferal with soybean DNA by ion beam. J. Henan Norm. Univ. (Nat. Sci.) 36: 154-156.

Ji SD, Chen P, Wang JC, Yuan Z et al. (2009). AFLP analysis of rice transformed with maize DNA by particle beam. $J$. Nucl. Agric. Sci. 23: 197-202.

Laemmli UK (1970). Cleavage of structural proteins during the assembly of the head of bacteriophage T4. Nature 227: 680-685.

Lu SX, Ji SD, Yue CH and Lan Y (2008). Seedling growth dynamic analysis on variant strains of low-protein of wheat transferal with soybean DNA by ion beam. J. Henan Norm. Univ. (Nat. Sci.) 36: 120-123.

Murray MG and Thompson WF (1980). Rapid isolation of high molecular weight plant DNA. Nucleic Acids Res. 8: 43214325 . 
Neuhaus-Steinmetz U, Xu C, Fracella F, Oberheitmann B et al. (1994). Heat shock response and cytotoxicity in C6 Rat Glioma cells: structure-activity relationship of different alcohols. Mol. Pharmacol. 45: 36-41.

Song D J, Yu X, Yao JM and Shao CL (1998). Studies on etching and damage action of low energy ion beam on microbial cells. Acta Biochim. Biophys. Sin. 30: 570-574.

Vasslli J and Pepper MS (1994). Tumour biology. Membrane proteases in focus. Nature 370: 14-15.

Wang SY, Ji SD, Chen P, Xue YZ, et al. (2008). Analysis of rice Yujing-8 proteinases by renaturation electrophoresis. Seed China 8: 40-42.

Xuan Y, Huang QC, Qin GY and Huo YP (2004). A electrophoretic survey of proteins and esterase isozyme of the progenies derived from transferring soybean DNA into wheat by ion beam. Acta Laser Biol. Sin. 13: 289-292.

Xu CS, Ji AL and Xia M (1998). Analysing activity and properties of lysosomal proteolytic enzymes by non-denatured electrophoresis. Henan Sci 16: 185-192.

Yu ZL (1998). Introduction to Ion Beam Biotechnology. Science and Technology Publishing House, Hefei, Anhui.

Yu ZL, Yang JB, Wu YJ, Cheng BJ et al. (1993). Transferring GUS gene into intact rice cells by low energy ion beam. Nucl. Instrum. Methods Phys. Res. B 81: 1328-1331.

Zhu XC, Liao XR and Fu ZG (2000). An analysis of variation characteristics of the progenies derived from introducing leymus racemosus gene into common wheat. Acta Univ. Agric. Boreali-Occidentalis 28: 6-10. 